\section{The Human Rights Act and mental health}

\section{legislation}

JONATHAN BINDMAN, SAMANTHA MAINGAY and GEORGE SZMUKLER

The Human Rights Act 1998 came into force in October 2000, bringing the rights set out in the European Convention on Human Rights into domestic law. Although many aspects of English mental health law have previously been tested against the European Convention on Human Rights in the European Court of Human Rights, it has been suggested that by removing the necessity to take 'the long road to Strasbourg', the Human Rights Act could result in a flood of legal cases concerning the management of mental disorder (Macgregor-Morris et al, 2001). We will consider the relationship between previous judgements in the European Court of Human Rights and domestic mental health law; review mental health cases brought under the Human Rights Act in its first year; and discuss its possible impact on clinical practice.

\section{THE EUROPEAN CONTEXT}

The important judgements of the European Court of Human Rights concerning mental health law have been reviewed in detail by Gostin (2000). Article 5 (Appendix 1) has received the most attention. The Court has considered the meaning of 'lawful detention', which must not be arbitrary and requires at least a minimally therapeutic environment. The meaning of 'unsound mind' has not been defined, although it should be based on 'objective medical expertise' and be of a 'kind or degree warranting compulsory confinement', and the validity of continued confinement depends upon the persistence of the disorder. Detention is a matter of the 'degree or intensity' of deprivation of liberty rather than its 'nature or substance'. This may exclude 'nonprotesting' patients, such as the subject of $R v$. Bournewood Community and Mental Health NHS Trust (1998), from the protection of article 5, and it has also been found that conditional discharge does not amount to 'deprivation of liberty'. A mental health review tribunal constitutes a court for the purposes of article 5(4), provided that it has the power to order discharge, and its power to do so was extended in the Mental Health Act 1983 in response to a judgement in the European Court of Human Rights ( $X$ $v$. United Kingdom, 1981). Coercive mental health care has also been challenged under article 3 , but the resulting jurisprudence is described by Gostin (2000) as 'highly deferential to mental health authorities'. The European Court of Human Rights has allowed force-feeding and physical restraint, by prolonged strapping to a bed, as 'medically justified' and declined to find that very poor conditions in prison hospitals or secure units were inhuman or degrading.

Deference to medical expertise, also apparent in domestic jurisprudence, may have been well intentioned. Declining to define what is meant by 'unsound mind', the European Court of Human Rights observed, in Winterwerp $v$. The Netherlands (1979), that 'it is a term whose meaning is continually evolving as research in psychiatry progresses, an increasing flexibility in treatment is developing and society's attitudes to mental illness change . . . so that a greater understanding of the problems of mental patients is becoming more widespread'. However, at a time when it appears to psychiatrists that mental health law reform is being driven by a change in society's attitudes in precisely the opposite direction (Royal College of Psychiatrists, 2001), this view may be out of date.

In summary, although the jurisprudence of the European Court of Human Rights has had some impact on the Mental Health Act 1983 and its interpretation, it has not set a high standard for modern mental health services. Some judgements may strike present-day clinicians not so much as protecting patients' rights but as permitting undesirable practices. This is perhaps not surprising when it is considered that the European Convention on Human
Rights, signed in 1950, harbours old prejudices against those with mental illness. These are apparent in the language of article 5, which groups persons of 'unsound mind' with 'vagrants' and 'drug addicts' as being exempted from the protections afforded to others. In incorporating the European Convention on Human Rights, the Human Rights Act perpetuates rather than challenges the lesser regard for the autonomy of patients with mental illness than of other medical patients, which is at the heart of conventional mental health legislation (Szmukler \& Holloway, 2000). Patients' capacity to make treatment decisions is essentially ignored.

\section{THE HUMAN RIGHTS ACT AND MENTAL HEALTH LAW}

A total of 192 cases raised human rights issues under the European Convention on Human Rights in the higher courts in the first year in which the Human Rights Act was in force (Human Rights Act Research Project, 2001). We reviewed these cases and identified seven in which the Mental Health Act 1983 or the actions of mental health services were at issue. We also consider a subsequent case below. Details of the cases are given in Appendix 2. Four of the seven cases related to the ability of the mental health review tribunal to meet the requirements of article 5(4). $R v$. MHRT London South (2001) established that routinely delaying hearings by 8 weeks was unacceptable. The case of $R v$. MHRT North and East London Region (2001) resulted in a declaration that sections 72 and 73 of the Mental Health Act 1983 are incompatible with the European Convention on Human Rights (one of only two such declarations in the first year of the Human Rights Act) because, rather than requiring that the lawfulness of continuing detention should be proven before a mental health review tribunal, these sections effectively reversed the burden of proof by requiring the patient to prove that the conditions for detention were no longer satisfied. A remedial order rewording these sections has been made, so that a mental health review tribunal must now direct the discharge of a patient if it is not satisfied that the conditions for detention are met. In East London and the City MH NHS Trust \& Snazell v. von Brandenberg (2001), deferred discharge by the mental health review tribunal was prevented by renewed detention before the 
patient could leave hospital and in $R v$. Camden and Islington Health Authority (2001), conditional discharge by the tribunal was prevented by failure to provide community care meeting the conditions. In both cases, it was argued that if the mental health review tribunal could not effect discharge, then article 5(4) would be breached, but neither case succeeded. In two cases concerning patients in special hospitals, it was argued that article 8 was violated by security measures (random monitoring of telephone calls and restricting visits by children) but again, neither case succeeded. Finally, a patient who was receiving treatment under the Mental Health Act failed in an attempt to argue that article 3 would be violated by his deportation to Malta, on the grounds that this might cause deterioration in his mental health and increase his risk of suicide.

\section{REFORM OF THE MENTAL HEALTH ACT}

The White Paper on the Reform of the Mental Health Act carries the necessary declaration that the proposed legislation will be fully compatible with the Human Rights Act (Department of Health, 2000). As discussed above, in many respects this is not a difficult test to meet. The most controversial aspects of the White Paper have been the proposal to introduce compulsory treatment in the community and the introduction of the concept of 'dangerous severe personality disorder' as the basis for detaining people with a diagnosis of personality disorder posing particular risks (Grounds, 2001). The use of the proposed Care and Treatment Order to require acceptance of treatment in the community is unlikely to be regarded as amounting to 'detention' under article 5. The order may also be insufficiently invasive or serious to violate articles 8 (respect for private and family life), 11 (freedom of association) or 13 (effective remedy for violation of rights), although the question remains open (Gostin, 2000). Detaining people who are diagnosed as having personality disorder and have been convicted of offences may be lawful under article 5(1)(a), even where the diagnosis can be challenged or the likely response to treatment is uncertain. For nonoffenders who have been diagnosed as having personality disorder, detention could be open to challenge on the grounds either that their disorder does not constitute, on 'objective medical expertise', a 'true mental disorder', or that detention could not be regarded as lawful for a condition not regarded as treatable (Council of Europe, 2000). However, the latter argument was rejected by the Scottish courts prior to the Human Rights Act and again, subsequently, on appeal to the Privy Council (Anderson and Others $v$. The Scottish Ministers and Another, 2001).

\section{CONCLUSIONS}

In mental health, as in other areas of law, the first year of the Human Rights Act has led to a steady trickle rather than a flood of cases, and few have successfully challenged existing practice. However, the Act may yet have a significant impact. The European Court of Human Rights tries to defer to national courts where possible to take account of the widely varying legal systems of the Contracting States (the 'margin of appreciation'), and this tends to make its jurisprudence conservative. The domestic courts are less constrained and can use the European Convention on Human Rights as a starting point for more radical changes. In addition, the Human Rights Act introduces the European doctrine of proportionality, which requires that any claimed exemption from the European Convention on Human Rights must be to the minimum extent possible. This may lead the domestic courts to go beyond the traditional process of judicial review, which tends to focus on the reasonableness of the decision-making process, and concern themselves with the actual merits of a doctor's decision (British Medical Association Committee on Medical Ethics, 2000). An early example of this is the case of $R v$. The Responsible Medical Officer Broadmoor Hospital and Others (2001), in which a patient sought judicial review of a decision to administer compulsory treatment. The court concluded that article 6 required that the court should investigate and resolve the medical issues, rather than restrict itself to scrutinising the decisionmaking process, and that the doctors should attend for cross-examination.

If the courts do begin to scrutinise the proportionality of clinical decisions (a function currently carried out only haphazardly by mental health review tribunals (Perkins, 2000)), the impact could be considerable.
Many of the cases involving the European Convention on Human Rights to date have concerned patients in maximum security or with significant forensic histories, and it is not surprising that continued detention and compulsory treatment are often found to be justified or the infringement of rights to be proportionate. However, a decision, for example, to compel a 'revolving-door' patient without a history of offending to accept community treatment might be judged to be disproportionate if founded on weak scientific evidence of risk or benefit.

Although some clinicians might not welcome increased scrutiny of professional judgements by the courts, others may see the benefits of a counterbalance to the increasing social and political pressures to treat coercively.

\section{DECLARATION OF INTEREST}

None.

\section{ACKNOWLEDGEMENTS}

We are grateful to Janet Arkinstall of the Human Rights Act Research Project for providing information and to Alec Buchanan, jill Peay and Geoffrey Bindman for their comments on the draft.

\section{APPENDIX I}

Selected extracts from the articles of the European Convention on Human Rights

Article 2

Everyone's right to life shall be protected by law.

\section{Article 3}

No one shall be subject to torture or to inhuman or degrading treatment or punishment.

\section{Article 5}

I. . . . no one shall be deprived of his liberty save in the following cases . . . (a) the lawful detention of a person after conviction by a competent court; (e) the lawful detention of persons for the prevention of the spread of infectious diseases, of persons of unsound mind, alcoholics or drug addicts, or vagrants;

4. Everyone who is deprived of his liberty by arrest or detention shall be entitled to take proceedings by which the lawfulness of his detention shall be decided speedily by a court and his release ordered if the detention is not lawful. 


\section{Article 6}

I. In the determination of his civil rights . . . everyone is entitled to a fair and public hearing within a reasonable period of time by an independent and impartial tribunal established by law.

\section{Article 8}

I. Everyone has the right to respect for his private and family life, his home, and his correspondence. . 2 . . . . except ... such as is ... necessary. . . for the protection of health . . . or for the protection of the rights and freedom of others.

\section{APPENDIX 2}

\section{Cases involving the Mental Health Act 1983 in the first year of the Human Rights Act 1998}

\section{Case relating to Article 3}

$R$ v. Secretary of State for the Home Department (200I). The Home Secretary sought to order the removal from England of an immigrant whose application for leave to remain in the UK had been refused. The immigrant was receiving treatment in hospital for schizophrenia under the Mental Health Act 1983 and applied for judicial review of the decision; this was dismissed and he appealed. The applicant submitted that if to move him would lead to an increased risk of self-harm and a deterioration in mental health, article 3 would be breached. The Court held that the proposed removal, if approved by a tribunal under section 86 of the Act, could not properly be described as inhuman or degrading treatment and could proceed.

\section{Cases relating to Article 5}

$R$ v. MHRT London South (200I). A patient detained under section 3 requested judicial review of a decision to list his mental health review tribunal hearing 8 weeks after his application. On appeal, it was successfully argued that article 5.4 required that the lawfulness of detention should be decided speedily, and European Court of Human Rights precedents suggested that 8 weeks was too long. An application for a hearing by a mental health review tribunal should be heard as soon as reasonably practicable, given the circumstances of the case, and should not be routinely delayed.

$R$ v. MHRT North and East London Region (200I). A patient detained under section $37 / 4$ I sought judicial review of a decision by the mental health review tribunal not to discharge him. The application was dismissed and he appealed. At issue was whether, under section 73 of the Mental Health Act 1983, the tribunal had to order discharge if it was not satisfied, on the basis of medical evidence, that the criteria for detention were met. The Court of Appeal held that sections 72 and 73 of the Act did not require the tribunal to discharge the patient, effectively placing the burden of proof on the patient to satisfy the tribunal that the conditions were not met. This contravened articles 5.1 and 5.4 , which

JONATHAN BINDMAN, SAMANTHA MAINGAY, GEORGE SZMUKLER, Section of Community Psychiatry (PRiSM), Institute of Psychiatry, London, UK

Correspondence: Jonathan Bindman, Section of Community Psychiatry (PRiSM), Health Services Research Department, Institute of Psychiatry, De Crespigny Park, Denmark Hill, London SE5 8 AF, UK. Tel: 0207848 0735; fax: 0207277 |462; e-mail: j.bindman@iop.kcl.ac.uk

(First received 22 November 200I, final revision 16 May 2002, accepted 29 May 2002)

require that it is positively established that detention is warranted. The wording of the sections has now been substituted so that the mental health review tribunal must discharge the patient if it is not satisfied that the criteria are met.

East London and the City MH NHS Trust \& Snazell v. von Brandenburg (200I). A patient was discharged from detention under section 3 of the Mental Health Act 1983 by the mental health review tribunal, deferred for 7 days. During the 7 days, he was again detained under section 3. An application for judicial review failed and he appealed. It was contended that if a tribunal's decision could be overridden without a change of circumstances being demonstrated by the relevant professionals, the tribunal would be denied the power to discharge required by article 5.4 The Court dismissed the appeal. It considered that if an application for readmission simply reflected that the responsible medical officer disagreed with the decision, then the tribunal decision would prevail or the application would be irrational; article 5.4 was not breached. In most cases where readmission was sought after a mental health review tribunal decision to discharge, discharge would have taken place or fluctuations in mental state were likely to have occurred. Provided that professionals were acting objectively and in good faith, they could conclude that the criteria for readmission were met without having to demonstrate a change of circumstances.

$R$ v. Camden and Islington Health Authority (200I). A patient detained under section 37/4I was granted a conditional discharge by a mental health review tribunal against medical advice. The conditions included community supervision by a responsible medical officer in the patient's home area, but no officer could be found who agreed that discharge was appropriate. It was contended that this thwarted the mental health review tribunal's power to discharge in breach of article 5.4. Dismissing the appeal, the Court held that if the necessary care could not be provided in the community, then it would not breach article 5 to continue to detain the patient. Health authorities must make reasonable efforts to meet mental health review tribuna conditions but they were not under an absolute obligation to do so. The Court would not act 'as a court of appeal from a psychiatrist on a question of clinical judgement' provided that the clinical judgement was made honestly, rationally and with due regard only to what is relevant.

\section{Cases relating to Article 8}

$R$ v. Ashworth Special Hospital Authority (200I). A patient detained under section $37 / 4$ I sought judicial review of the policy in special hospitals of randomly monitoring $10 \%$ of telephone calls made by nonhigh-risk patients. At issue was the balance between the right to privacy under article 8.1 and the exemption permitted under article 8.2 to protect the rights of others. The Court noted that there was compelling evidence that, unless prevented, patients were likely to misuse telephones to give rise to risk to others. The interference with article 8.1 in this case was in proportion to the necessity to achieve a legitimate security aim and it could continue.

$R$ v. Secretary of State for Health (200I). A patient detained under section 37/4I applied for judicial review of a decision to prevent visits by his nephews and nieces, pending risk assessment, following directions issued by the Secretary of State regulating visits by children to patients convicted of serious offences. In fact, the directions did not exclude the visits requested in this case, but it was argued that they interfered with family life, contrary to article 8.I. The Court held that the European Convention on Human Rights allowed the Secretary of State wide discretion in deciding where the balance between the rights of children and of patients should be struck, and the directions were not disproportionate.

\section{REFERENCES}

British Medical Association Committee on Medical Ethics (2000) The impact of the Human Rights Act 1998 on medical decision making. London: British Medical Association. http://www.cirp.org/library/ legal/BMA-human-rights/

Council of Europe (2000) White Paper on the protection of human rights and dignity of people suffering from mental disorder, especially those placed as involuntary patients in a psychiatric establishment. Strasbourg: Council of Europe.

Department of Health (2000) Reforming the Mental Health Act. Part I. The new legal framework. London: Stationery Office.

Gostin, L. O. (2000) Human rights of persons with mental disabilities. The European Convention on Human Rights. International Journal of law and Psychiatry, 23, 125-129.

Grounds, A. (200I) Reforming the Mental Health Act. British Journal of Psychiatry, 179, 387-389.

Human Rights Act Research Project (200I) Monitoring the Human Rights Act. London School of Economics and Doughty Street Chambers. http: // 
www.doughtystreet.co.uk (follow links to HRARP Project - statistical analysis).

Macgregor-Morris, R., Ewbank, J. \& Birmingham, L (200I) Potential impact of the Human Rights Act on psychiatric practice: the best of British values. British Medical Journal, 322, 848-850.

Perkins, E. (2000) Decision-making in Mental Health Review Tribunals. In Shaping the New Mental Health Act Key Messages from the Department of Health research Programme. http://www.doh.gov.uk/mhar/ mha_use.htm

Royal College of Psychiatrists (200I) White Paper on the Reform of the Mental Health Act 1983: Letter from the Chair of the College's Public Policy Committee. http://www.rcpsych.ac.uk/college/parliament/ responses/wpReg.htm
Szmukler, G. \& Holloway, F. (2000) Reform of the Mental Health Act: Health or safety? British Journal of Psychiatry, 177, 196-200.

Anderson and Others v. The Scottish Ministers and Another (200I) Times Law Report 29 October

East London and the City MH NHS Trust \& Snazell v. von Brandenburg (200I) 3 WLR 588.

$R v$. Ashworth Special Hospital Authority, ex parte N (200I) Times Law Report 26 June.

$R$ v. Bournewood Community and Mental Health NHS Trust, ex parte L (1998) 3 All ER 289.

$R$ v. Camden and Islington Health Authority, ex parte $K$ (200I) 3 WLR 553
R v. MHRT London South, ex parte C (200I) Lloyds Rep Med 340.

$R$ v. MHRT North and East London Region, ex parte $H$ (200I) 3 WLR 512

$R v$. Secretary of State for Health, ex parte L (200I) Times Law Report 26 October.

$R v$. Secretary of State for the Home Department ex parte $X$ (200I) Times Law Report 9 January 200I (Judgement II October 2000).

$R v$. The Responsible Medical Officer Broadmoor Hospita and Others, ex parte Wilkinson (200I) EWCA Civ 1545, Times Law Report 2 November.

Winterwerp v. The Netherlands (1979) 2 EHRR 387.

X v. United Kingdom (198I) I BMLR 98 